удК 001.891, 001.891:070

\title{
ОСОБЛИВОСТІ ОРГАНІЗАЦІї ІНФОРМАЦІЙНО-МЕДІЙНОГО ЗАБЕЗПЕЧЕННЯ У ВІЙСЬКОВІЙ СФЕРІ
}

\author{
FEATURES OF THE ORGANIZATION \\ OF INFORMATION AND MEDIA SUPPORT \\ IN THE MILITARY SPHERE
}

\author{
Олієвська Мирослава Григорівна \\ доктор економічних наук, доцент, \\ Військовий інститут \\ Київського національного університету імені Тараса Шевченка \\ ORCID: https://orcid.org/0000-0001-8818-0509 \\ Olievska Myroslava \\ Military Institute of Taras Shevchenko National University of Kyiv
}

\begin{abstract}
Досліджено особливості організації інформаційно-медійного забезпечення у військовій ссрері. У статті зазначено, що створення та поширення інорормації медійними структурами Міністерства оборони України відбувається 3 дотриманням правил та обмежень, і в рамках нормативно-правового поля. Запропоновано Методику визначення трудомісткості та вартості робіт з розробки медіа контенту як інструмент підвищення есрективності праці авторів (виконавців) мілітаріконтенту. Методика складається з таких етапів: визначення трудомісткості розробки одиниці медіаконтенту; визначення поправочних коесріцієнтів; визначення трудомісткість розробки одиниці медіаконтенту з урахуванням поправочних коефіцієнтів, які оцінюють якість контенту, час його розробки; визначення вартості робіт з розробки медіа контент.

Ключові слова: інфрормаційне та медіазабезпечення, військова сфера, трудомісткість, методика визначення трудомісткості та вартості робіт з розробки медіаконтенту, етапи визначення трудомісткості, поправочні коефіцієнти.
\end{abstract}

Исследованы особенности организации информационно-медийного обеспечения в военной сфере. В статье отмечено, что создание и распространение инорормации медийными структурами Министерства обороны Украины происходит с соблюдением правил и ограничений и с учетом нормативно-правовых актов. Предложена Методика определения трудоемкости и стоимости работ по разработке медиаконтента является инструментом повышения эффективности труда авторов милитариконтента. Методика состоит из следующих этапов: определение трудоемкости разработки единицы медиаконтента; определение поправочных коэфрфициентов; определение трудоемкости разработки единицы медиаконтента с учетом поправочных коэфрфициентов, оценивающих качество контента, время его разработки; определение стоимости работ по разработке медиаконтента.

Ключевые слова: информационное и медиаобеспечение, военная сфера, трудоемкость, методика определения трудоемкости и стоимости работ по разработке медиаконтента, этапы определения трудоемкости, поправочные коэффрициенты.

SuThe features of the organization of information and media support in the military sphere were investigated. The article states that the creation and dissemination of information by the media structures of the Ministry of Defense of Ukraine and the Armed Forces of Ukraine is in compliance with the rules and restrictions, and within the regulatory framework. It is determined that media content in modern society into information is a set of diverse information aimed at the target audience and transmitted through printed, audiovisual and other content. Emphasis is placed on the fact that the creation of media content is a structured creative and production process that requires from the author both deep knowledge of the theory and methods of writing texts, and practical skills of technical means. It is determined that the development of media content depends on a number of factors, which are structured in two groups: factors related to media development, its complexity and specificity; factors that depend on the knowledge, skills, professionalism and personal characteristics of the performer (author). The Methods for determining the labor 
intensity and cost of work on the development of media content as a tool to improve the efficiency of authors (performers) of military content is proposed. It is established that the labor intensity of work on the development of media content is a basic standard of labor intensity in its creation, adjusted by correction factors. The Methods consists of the following stages: determining the complexity of developing a unit of media content; determination of correction factors; determining the complexity of developing a unit of media content, taking into account correction factors that assess the quality of content, the time of its development; determining the cost of work on media content development. It is argued that the use of the Methods for determining the labor intensity and cost of work on the development of media content by information and media structures of the Ministry of Defense of Ukraine and the Armed Forces of Ukraine is one of the tools for implementing of state information policy on national security in the military sphere, both in wartime and in peacetime for effective and comprehensive information of the population.

Keywords: information and media support, the military sphere, the labor intensity, Methods for determining the labor intensity and cost of work on the development of media content, stages of determining the labor intensity, corrections factors.

Постановка проблеми. У рамках сучасного інсрормаційного простору, ознаками якого є суттєве зростання ролі інформації та знань, збільшення числа людей, зайнятих інформаційними технологіями, комунікаціями та виробництвом інформаційних продуктів, а також позитивна динаміка частки таких продуктів у валовому внутрішньому продукті, створення та розповсюдження контенту має свої особливості та чинники розвитку. Не виключенням є військова сорера, інорормаційно-медійні структури якої виконують завдання із реалізації державної інфрормаційної політики щодо національної безпеки у воєнній сорері, сорерах оборони і військового будівництва в мирний час та особливий період з метою всебічного об'єктивного інформування про діяльність Міністерства оборони України (МОУ) [7]. Більше того, про значення інфрормаційно-психологічних засобів впливу та роботу медіа йдеться як у Стратегії національної безпеки України [5], так і у Національній економічній стратегії на період до 2030 року [6].

Відтак, важливим завданням у діяльності Уряду, МОУ та Збройних Сил України (3СУ) $€$ впровадження сучасних інфрормаційних технологій і фрормування якісного контенту для ефрективного інфрормаційного забезпечення не лише військовослужбовців, але й інших споживачів інформації, суспільства в цілому. Суб'єктами сучасного інфрормаційного простору $є$ як традиційно класичні засоби масової інфрормації, так і новітні крос-медійні проекти, що продукують численні інфрормаційні продукти на основі використання технологічних можливостей Інтернету.

Формування медійного простору в Україні, серед іншого, залежить від розробки методичних підходів з визначення трудомісткості та вартості робіт з розроблення медіаконтенту.

Аналіз останніх досліджень і публікацій. Питання щодо створення та поширення медіаконтенту є предметом наукових пошуків таких учених як Владимиров В. [1], Горська К. [2], Даниленко С. [3], Михайлин І., Садівничий В., Требін М. [10], Шевченко В. [4] та ін. Особливості сучасних комунікаційно-контентних процесів у військовій сорері досліджують Клубань О., Курбан О., Любовець Г., Король В., Савчук Р. [9] та ін. У своїх публікаціях науковці обґрунтовують значення та особливості використання медіа для впливу на цільову аудиторію.

У публікаціях зазначається, що медіа $€$ ефективним інструментом як підтримки суспільної рівноваги, так і інформаційного тероризму. Прикладом такого інформаційного тероризму науковці називають скеровану керівництвом Росії діяльність засобів масової інфрормації під час «гібридної» війни проти нашої держави [10].

Виділення невирішених раніше частин загальної проблеми. Актуальність розробки методичних підходів з визначення трудомісткості та вартості робіт з розроблення медіа контенту тісно пов'язана з необхідністю удосконалення процесів створення медіаконтенту, що є актуальною науковою проблемою, суть якої полягає у обґрунтуванні теоретикометодичних підходів з визначення трудомісткості та вартості робіт з розроблення медіаконтенту у сорері національної безпеки і визначення на цій основі пріоритетних напрямів удосконалення цього процесу.

Формулювання цілей статті (постановка завдання). Удосконалення процесів створення медіаконтенту вимагає обґрунтування теоретико-методичних підходів з визначення трудомісткості та вартості робіт з розроблення медіаконтенту у сфрері національної безпеки.

3 огляду на це, мета статті - проаналізувати особливості організації інфрормаційномедійного забезпечення у військовій сфері та 
визначити напрями удосконалення підходів щодо визначення трудомісткості розробки медіаконтенту.

Виклад основного матеріалу дослідження. У сучасних умовах стрімкого науковотехнічного прогресу та жорсткої інформаційної протидії для забезпечення повсякденної діяльності МOУ та ЗСУ особливо важливими постають питання впровадження сучасних комунікаційно-контентних технологій з метою формування якісного медійного контенту для надійного інформаційного забезпечення військовослужбовців, а також об'єктивного, оперативного і ефективного інформування суспільства щодо процесів, які відбуваються в оборонному секторі.

3 цього приводу науковці зазначають, що взаємодія між військовим сектором та медіа ніколи не буває простою, а тим більше, в ситуації збройного та цивілізаційного конфрлікту. Значимість інфрормаційного контенту доходить того рівня, коли визначає сутність основних суспільних процесів, серед яких особливе місце посідає сектор оборони і безпеки [9].

При цьому створення та розповсюдження медіаконтенту у військовій сорері має свої особливості. Як зазначають науковці, «за інфрормуванням суспільства під час бойових дій мають бути установлені певні правила, від їх дотримання усіма сторонами комунікаційного процесу стоять життя людей, безпека держави і доля країни. Історії відомо багато прикладів того, як непродумане і безсистемне інформування суспільства про події в умовах проведення антитерористичної операції шкодить військовим у виконанні ними завдань за призначенням» [9].

Відтак, створення медіаконтенту поширення медійних розробок у забезпеченні повсякденної діяльності МОУ та ЗСУ має свої особливості, зокрема:

- діяльність військових тісно пов'язана 3 конфіденційністю, на якій побудована вся система відносин і фрункціонування мілітарнобезпекового сектору будь-якої держави;

- виконуючи завдання, журналісти переконані, що люди мають право знати все, що іноді суперечить позиції військових, які вважають, що можна «знати в такому обсязі і тоді, коли це не зашкодить національній безпеці, виконанню завдань за призначенням, їх підрозділу, і насамперед, не несе загрози життю кожного 3 них»;

- між пресою та військовими можлива взаємодія [9].
Задля досягнення цілей інфрормування в Україні у вересні 2020 року було утворено новий структурний підрозділ - Управління преси та інформації, який $є$ самостійним структурним підрозділом Центрального апарату. Управління підпорядковується Міністру оборони України.

Діяльність Управління спрямовує та координує заступник МОУ, а основні завдання і функції Управління визначені наказом МОУ від 22.09.2020 року № 347 «Про затвердження Положення про Управління преси та інформації Міністерства оборони України» [7].

Управління виконує завдання із реалізації державної інфрормаційної політики з питань національної безпеки у воєнній сорері, сорерах оборони і військового будівництва в мирний час та особливий період з метою всебічного об'єктивного інформування про діяльність MOУ, здійснює заходи з формування позитивної громадської думки щодо Міноборони, Збройних Сил України та Державної спеціальної служби транспорту, організує взаємодію із засобами масової інфрормації.

Основними завданнями Управління є фрормування, забезпечення реалізації державної політики з питань національної безпеки у сорері його компетенції на основі постійного аналізу стану справ у мирний час та особливий період щодо:

- орормування та реалізації єдиної інорормаційної політики в Міноборони та ЗСУ;

- визначення цілей та завдань інформаційної діяльності Міноборони, основних напрямів і механізмів її реалізації;

- інформування громадськості про діяльність Міноборони, ЗСУ;

- постійного моніторингу інорормаційного середовища, виявлення інформаційних загроз у сорері оборони, здійснення відповідних заходів інформаційної протидії в межах компетенції;

- прогнозування інформаційних ризиків під час взаємодії Міноборони, ЗСУ та громадськості, підготовка відповідних пропозицій щодо реагування на них;

- забезпечення в межах повноважень, створення необхідних умов та здійснення демократичного цивільного контролю за діяльністю ЗСУ, інфрормування із зазначених питань громадськості та медіа.

Відповідно до наданих повноважень, Управління преси та інфрормації, серед іншого, забезпечує реалізацію державної інфрормаційної політики в Міноборони, ЗСУ; бере участь у заснуванні телерадіоорганізації 
та здійснює керівництво їх діяльністю; розробляє і бере участь у розробленні проектів законів та інших нормативних актів відповідно до напряму діяльності Управління, здійснює в установленому порядку їх погодження та супроводження; готує самостійно або разом з іншими структурними підрозділами, інсрормаційні та аналітичні матеріали; забезпечує доступ до публічної інфрормації, розпорядником якої $є$ Управління; а також забезпечує інформаційний супровід діяльності Міноборони, ЗСУ.

У підпорядкуванні Управління перебувають такі медійні установи:

1. Центральна телерадіостудія Міністерства оборони України - один із підрозділів у системі інфрормаційно-медійних структур ЗСУ, який в умовах відбиття російської збройної агресії проти України інорормує наше суспільства про готовність ЗСУ виконувати завдання за призначенням. Наразі у вільному доступі в усіх українців сучасний мілітаріконтент 3 району проведення ООС, телевізійні проєкти, документальна аналітика, реаліті шоу, військове радіо.

2. АрміяINFORM - інформаційне агентство MOУ [8], створене у грудні 2018 року з метою розроблення якісного інфрормаційного продукту на засадах об'єктивності й неупередженості в редакційній політиці, а також цілодобового доступу до новин. Щодня АрміяINFORM дає повну картину подій у сорері оборони і безпеки: оперативна інфрормація, аналітика, ексклюзивні коментарі, інтерв'ю, фроторепортажі, інфрографріка, відеостріми з місця події. AрміяINFORM має мережу корпунктів. Кореспонденти агентства працюють у всіх регіонах України, зокрема постійно в районі проведення OOC. Пресцентр АрміяINFORM забезпечує профресійну підготовку, проведення та комплексний медіа супровід прес-конфреренцій, бриорінгів, круглих столів, інтернет-конференцій, презентацій, семінарів, виставок.

Згадані інфрормаційно-медійні установи сьогодні активно функціонують в системі стратегічних комунікацій оборонного сектору, виконуючи завдання за призначенням, наповнюють відповідним контентом інформаційний простір, проявляючи досить помітну активність в публічних полях локального, національного i міжнародного рівня. Щодо сутності самого контенту, то він $€$ досить різноплановим за своїм змістом, дизайном і представлений широким жанровим розмаїттям.

Медійний контент, який продукується відомчими профрільними установами та розповсю- джується як в системі внутрішніх, так і зовнішніх комунікацій МОУ та ЗСУ можна об'єднати у такі групи як друкований (текстовий) медіаконтент; аудіовізуальний та інший медіаконтент. Його носіями є: Інтернет ресурси; публічні платформи в соціальних мережах; електронні засоби масової інфрормації (радіо, телебачення); друковані засоби інсрормації; спеціалізовані видання; рекламно-презентаційна продукція.

Таким чином, в компетенції військових медіа - підготовка і розповсюдження відповідного контенту, формування інфрормаційної підтримки діяльності МОУ та ЗСУ. Проте, сам процес розробки складається з низки робіт і $\epsilon$ доволі складним як з точки зору використання сучасних технічних засобів, так і з точки зору залучення людських ресурсів.

На наш погляд, задля систематизації, наповнення науковим змістом такого складного і творчого процесу як розробка медіаконтенту, а також 3 метою підвищення ефективності праці авторів (виконавців), поширення якісного контенту, доцільно розробити Методику визначення трудомісткості та вартості робіт 3 розробки медіаконтенту.

Відповідно до авторської Методики на першому етапі визначається трудомісткість розробки одиниці медіаконтенту 3 урахуванням базових нормативів трудомісткості розробки друкованого та аудіовізуального медіаконтенту, отриманих експертним методом.

На другому етапі визначаються поправочні коефіцієнти, які доцільно згрупувати таким чином:

1) Коефріцієнт оцінювання якості медійної розробки $\left(\mathrm{K}_{я}\right)$ :

$$
\begin{aligned}
& \mathrm{K}_{\mathrm{g}}=\mathrm{K}_{\mathrm{a}} \text { * } \mathrm{K}_{\text {оп }} \text { * } \mathrm{K}_{\mathrm{o}} \text { * } \mathrm{K}_{\mathrm{p}} \text { * } \mathrm{K}_{\mathrm{H}} \text { * } \mathrm{K}_{\mathrm{i}} \text { * } \mathrm{K}_{\text {eq }} \text { * } \\
& \text { * } \mathrm{K}_{\mathrm{K}} * \mathrm{Ke} * \mathrm{~K}_{\mathrm{rp}} * \mathrm{~K}_{\mathrm{Ba}} * \mathrm{~K}_{\mathrm{\phi 巾}} \text { * } \mathrm{K}_{\text {пн }}
\end{aligned}
$$

де $\mathrm{K}_{\mathrm{a}}$ - коефріцієнт актуальності; $\mathrm{K}_{\text {оп }}$ - коефріцієнт оперативності подачі медіа контенту; $\mathrm{K}_{\mathrm{o}}$ - коефріцієнт об'єктивності; $\mathrm{K}_{\mathrm{p}}$ - коефріцієнт рейтинговості медіа контенту; $\mathrm{K}_{\mathrm{H}}$ - коесріцієнт новизни; $\mathrm{K}_{\mathrm{i}}-$ коефріцієнт інфрормативності; $\mathrm{K}_{\text {еф }}$ - коефріцієнт впливу контенту; $\mathrm{K}_{\mathrm{k}}$ - коефріцієнт компетентності; К виконавця (автора); $\mathrm{K}_{\mathrm{kp}}$ - коефріцієнт креативності виконавця (автора); $\mathrm{K}_{\text {ва }}$ - коесріцієнт відповідальності; $\mathrm{K}_{\text {фн }}$ - коефіцієнт фрізичної небезпеки; $\mathrm{K}_{\text {пн }}$ - коефріцієнт психологічної небезпеки.

2) Коесріцієнт оцінювання витраченого чacy $\left(K_{4}\right)$ :

$$
\mathrm{K}_{4}=\mathrm{K}_{\mathrm{cp}} \text { * } \mathrm{K}_{\mathrm{K}} \text { * } \mathrm{K}_{\mathrm{T} 3} \text { * } \mathrm{K}_{\text {iм }}
$$

де $\mathrm{K}_{\mathrm{cp}}$ - коефріцієнт складності розробки медіа контенту; $\mathrm{K}_{\text {к }}$-коесріцієнт комплексності; 
$\mathrm{K}_{\text {тз }}$ - коефріцієнт використання технічних засобів; $\mathrm{K}_{\text {ім }}$ - коефріцієнт інформаційної місткості.

3) Коесріцієнту оцінювання витраченого часу та якості контенту (Кч/я):

$$
\mathrm{K}_{\mathrm{u} / 9}=\mathrm{K}_{\Pi} * \mathrm{~K}_{3 л}
$$

де $\mathrm{K}_{\text {п }}$ - коефріцієнт профресіоналізму/досвідченості виконавця (автора); $\mathrm{K}_{3 л}-$ коесріцієнт злагодженості колективу виконавців (авторів).

Коефіцієнти обираються 3 урахуванням того, що: коесріцієнт актуальності визначає наскільки медіаконтент відповідає запитам цільової аудиторії, несе суспільно корисну інфрормацію; коефріцієнт оперативності медіаконтенту застосовується до медійних розробок, які максимально оперативно, своєчасно та актуально висвітлюють події, проте не в збиток іншим стандартам; коефріцієнт об'єктивності застосовується для розробок, зміст, структура та трудомісткість яких змінюється із зростанням кількості фрактів, які досліджуються; коефріцієнт достовірності медіаконтенту використовується як підтвердження того, що інформація відповідає дійсності, і не несе в собі контент пропагандистського типу; коесріцієнт рейтинговості враховує рейтинг медіа; коефріцієнт складності розробки медіа контенту застосовується в залежності від обсягів запланованих завдань, які потрібно виконати, щоб створити одиницю контенту; коефіцієнт новизни медіаконтенту враховує ступінь новизни самого творчого процесу; коеоріцієнт комплексності враховує залежність нормативної трудомісткості процесу розробки від кількості виконавців (авторів); коефріці$€ н т$ використання технічних засобів враховує залежність трудовитрат на розробку медіаконтенту від потреби використання технічних засобів; коефріцієнт інформативності враховує обсяг корисної інсрормації для споживання цільовою аудиторією; коесріцієнт інсрормаційної місткості застосовується в разі збільшення інфрормаційного наповнення або тривалості одиниці медіа контенту; коефріцієнт впливу медіаконтенту враховує вплив медіаконтенту на цільову аудиторію; коефріцієнт профресіоналізму виконавця враховує залежність трудовитрат від рівня досвіду виконавця (автора) або колективу виконавців (авторів); коефріці$€$ єт компетентності визначає наскільки автор медійного контенту орієнтується в обраній темі; коесріцієнт емпатії використовується у разі, якщо розробка медіаконтенту супроводжується морально-психологічним навантаженням на виконавця (автора); коефріцієнт креативності виконавця враховує його творчі здібності; коефіцієнт відповідальності враховує усвідомлення автором контенту суті та значення медійної діяльності, її наслідків для суспільства і соціального розвитку; коефріцієнт небезпеки описує можливі варіанти безпечної або небезпечної діяльності; коефріцієнт злагодженості колективу виконавців (авторів) характеризує злагодженість в роботі редакційного (творчого) колективу, взаємодію в організації творчого процесу, можливість взаємозаміни. Значення коефріцієнтів в межах 0,5-1,5.

На третьому етапі визначається трудомісткість розробки кожної одиниці медіаконтенту $\mathrm{T}_{\text {o }}$ у урахуванням поправочних коефріцієнтів за фрормулою:

$$
\mathrm{T}_{\mathrm{o}}=\sum_{\mathrm{j}=1}^{m} \mathrm{~T} \text { * } \mathrm{K}_{4} \text { * } \mathrm{K}_{\mathrm{g}} \text { * } \mathrm{K}_{\mathrm{u} / \mathrm{g}}
$$

де $\mathrm{K}_{4}$ - коефріцієнт оцінювання витраченого часу; $\mathrm{K}_{я}$ - коесріцієнт оцінювання якості розробки; $\mathrm{K}_{4 / я}-$ коесріцієнт оцінювання часу та якості розробки; Т - трудомісткість розробки одиниці друкованого/аудіовізуального медіаконтенту; j - поточний номер одиниці медіаконтенту; m - кількість одиниць медіаконтенту.

На четвертому етапі визначається собівартість робіт з розробки медіа контенту за фрормулою:

$$
\mathrm{B}=\mathrm{T}_{\mathrm{p}} * \text { ОП год }
$$

де $T_{p}$ - трудомісткість розробки медіаконтенту, людино-год.; ОП год - оплата праці працівників за год, грн.

Висновки. Питання створення та розповсюдження медіаконтенту, набувають додаткової актуальності в умовах інфрормаційного суспільства, нових викликів тощо, коли якість, доступність, достовірність, своєчасність подання медійного контенту в тому чи іншому форматі активно впливає на всі процеси життєдіяльності, і це дає підстави вважати, що сучасне суспільство дедалі більше залежить від інфрормаційних потоків, сорормованих розробниками медіаконтенту.

Проте, фрормування медійного простору в Україні відбувається в умовах нессормованого нормативно-правового поля. Частково усунуту загрози та вирішити проблему щодо визначення трудомісткості та вартості робіт 3 розроблення медіаконтенту можна за умови використання запропонованої Методики визначення трудомісткості і вартості робіт 3 розробки медіаконтенту, яка встановлює базові нормативи трудомісткості робіт з розробки медіаконтенту, поправочні коефіцієнти, порядок визначення трудомісткості, загальної трудомісткості та вартості робіт з розробки медіаконтенту. Ця Методика може бути реко- 
мендована для застосування інформаційномедійними структурами Міністерства оборони України та Збройних Сил України під час створення медіаконтенту, а також фрізичними або юридичними особами незалежно від організаційно-правової форми та форми власності, які створюють медіаконтент, у частині визначення трудомісткості робіт з його розробки.

\section{СПИСОК ВИКОРИСТАНИХ ДЖЕРЕЛ:}

1. Владимиров В.М. Журналістика, особа, суспільство: проблема розуміння : монографрія. Київ. нац. ун-т ім. Т. Шевченка. Ін-т журналістики, 2003. 281 с.

2. Горська К.О. Медіаконтент цифрової доби: трансфрормації та фрункціонування : дис. д-ра соц. ком. наук : 27.00.01. Київ. нац.ун-т імені Тараса Шевченка, 2016. 449 с.

3. Даниленко С. Перевтілення демократії в інформаційну добу: роль нових медіа та громадянського комунікування. Політичні дослідження. 2021. № 1. С. 90-105.

4. Кросмедіа: контент, технології, перспективи : колективна моногр. / за заг. ред. д. н. із соц. ком. В.Е. Шевченко; Інститут журналістики Київського національного університету імені Тараса Шевченка. Київ, 2017. 234 с.

5. Про рішення Ради національної безпеки і оборони України від 14 вересня 2020 року «Про Стратегію національної безпеки України»: Указ Президента України від 14 вересня 2020 року № 392/2020. URL: https://www.president.gov.ua/documents/3922020-35037

6. Про затвердження Національної економічної стратегії на період до 2030 року : Постанова КМУ від 03 березня 2021 p. № 179. URL: https://www.kmu.gov.ua/npas/pro-zatverdzhennya-nacionalnoyi-eko-a179

7. Про затвердження Положення про Управління преси та інформації Міністерства оборони України : наказ Міністерства оборони України від 22.09.2020 року № 347. URL: https://www.mil.gov.ua/content/mou_orders/ mou_2020/mou_347.pdf

8. Про затвердження Статуту Інформаційного агентства : Наказ Міністерства оборони України від 17.12.2018 p. № 633. URL: https://www.mil.gov.ua/content/mou_orders/633_nm_2018.pdf

9. Сучасні комунікаційно-контентні процеси в безпековій ссрері : навчальний посібник / Клубань О.М., Курбан О.В., Любовець Г.В., Король В.Г., Савчук Р.П. Київ : ВІКНУ, 2016. 170 с.

10. Требін М.П. «Гібридна» війна як нова українська реальність. Український соціум. 2014. № 3. С. 113-127.

\section{REFERENCES:}

1. Vladymyrov, V. M. (2003) Zhurnalistyka, osoba, suspilstvo: problema rozuminnia: monohrafiia. Kyiv. nats. un-t im. T. Shevchenka. In-t zhurnalistyky, 281.

2. Horska, K. (2016) Mediakontent tsyfrovoi doby: transformatsii ta funktsionuvannia: dys. d-ra sots. kom. nauk: 27.00.01. 449.

3. Danylenko, S. (2021) Perevtilennia demokratii v informatsijnu dobu: rol novykh media ta hromadianskoho komunikuvannia. Politychni doslidzhennia, vol. 1, 90-105.

4. Krosmedia: kontent, tekhnolohii, perspektyvy: kolektyvna monohr. (2017) / za zah. red. d. n. iz sots. kom. V. E. Shevchenko; Instytut zhurnalistyky Kyivskoho natsionalnoho universytetuimeni Tarasa Shevchenka. Kyiv, 234.

5. Pro rishennia Rady natsionalnoi bezpeky i oborony Ukrainy vid 14 veresnia 2020 roku «Pro Stratehiiu natsionalnoi bezpeky Ukrainy»: Ukaz Prezydenta Ukrainy vid 14 veresnia 2020 roku № 392/2020. Available at: https://www.president.gov.ua/documents/3922020-35037

6. Pro zatverdzhennia Natsionalnoi ekonomichnoi stratehii na period do 2030 roku: Postanova KMU vid 03 bereznia 2021 r. № 179. Available at: https://www.kmu.gov.ua/npas/pro-zatverdzhennya-nacionalnoyi-eko-a179

7. Pro zatverdzhennia Polozhennia pro Upravlinnia presy ta informatsii Ministerstva oborony Ukrainy: nakaz Ministerstva oborony Ukrainy vid 22.09.2020 roku № 347. Available at: https://www.mil.gov.ua/content/mou_orders/ mou_2020/mou_347.pdf

8. Pro zatverdzhennia Statutu Informatsijnoho ahentstva: Nakaz Ministerstva oborony Ukrainy vid 17.12.2018 r. № 633. Available at: https://www.mil.gov.ua/content/mou_orders/633_nm_2018.pdf

9. Suchasni komunikatsijno-kontentni protsesy v bezpekovij sferi: navchalnyj posibnyk (2016) / Kluban O.M., Kurban O.V., Liubovets H.V., Korol V.H., Savchuk R.P. Kyiv: VIKNU, 170.

10. Trebin, M. (2014) «Hibrydna» vijna iak nova ukrainska realnist. Ukrainskyj sotsium, vol. 3, 113-127. 